\title{
PERSONALITATEA UMANĂ. REFLECṬII GENERALE
}

\section{Trip Gheorghe}

\author{
${ }^{1}$ Spitalul Județean de Urgență Satu Mare, medic primar cardiolog
}

Este ușor de înțeles că binele omului și tot traiul lui va depinde mai ales de ceea ce se află în el însuși și ceea ce se petrece înăuntrul lui. Acolo se naște de-a dreptul dispoziția lui bună sau rea, care este mai întâi rezultatul sensibilității, impresionabilității, voinței și gândirii lui, adică adevărata lui realitate, pe când toate lucrurile din afară nu au decât o influență indirectă asupra acestuia.

Lumea în care trăiește fiecare, depinde în primul rând de modul fiecărei persoane de a o vedea, adică percepția asupra lumii a fiecăruia depinde în mod special de deosebirea entităților mentale: astfel dupa cum sunt entitățile, va deveni și viața săracă, șubredă și goală, sau bogată, interesantă și plină de importanță. Astfel o persoană poate ajunge să admire omul pentru întâmplările interesante din viața lui, în loc să-l admire mai cu seamă pentru talentul lui înăscut de observație și de sensibilitatea prin care acele întâmplări au caștigat însemnătatea lor. Căci aceași întâmplare care într-un cap plin de spirit capătă o valoare deosebită și interesantă, rămâne din pacate o întâmplare obișuită și de rând dacă se răsfrânge într-un cap „sec”. Cel mai bine se poate observa în percepțiile individuale ale persoanelor asupra operelor unor mari poeți ca Goethe sau Byron: unii percep aceste opere ca fiind urmarea unor întâmplări reale, iar un cititor neavizat este în stare sa-l invidieze pe poet pentru întâmplarea cea fericită, în loc să-l invidieze pentru puternica lui fantezie și capacitate de exprimare, care dintr-o istorie de toate zilele a fost capabil să produca o operă atât de plăcută și valoroasă. În acest sens se poate spune clar că melancolicul vede o scena tragică, sangvinicul va vedea numai un conflict interesant, iar flegmaticul un lucru fără însemnătate.

Astfel pentru a vorbi mai familiar: fiecare este adâncit în conștiința sa ca și în pielea sa și trăiește numai în ea; de aceea nici nu i se poate da un ajutor din afară. Pe scena vieții, la vedere, unul ajunge ministru, altul patron, soldat sau general, etc. însă aceste deosebiri sunt numai pe dinafară, înăuntrul miezului unei astfel de înfățișări spirituale se află la toți același lucru: un biet comediant cu grijile și nevoile lui. Dacă prin avere și titluri fiecare are un rol diferit de jucat fără a-i produce o modificare internă în tihna și liniștea sufletească, se poate observa foarte clar faptul că în fiecare din noi se ascunde același sărman muritor cu nevoile și neajunsurile lui, nevoi care din punct de vedere material sunt diverse, dar în privința adevăratei firi, a individualității structurale sunt aceleași pentru toți. Căci tot ce există și se întâmplă pentru un om, există în mod hotărât numai în conștiința lui și se întâmplă în mintea fiecarei persoane în parte, astfel încât calitatea conștiinței este de mare importanță pentru personalitatea fiecăruia. De aceea, toată strălucirea și toate petrecerile oglindite sau reflectate în conștiința alterată a unui nerod, sunt foarte sărace față de conștiința lui Cervantes când scria despre don Quijote într-o temniță întunecoasă.

Se poate înțelege că viața fiecărui om, cu toate schimbările și prefacerile din afară, are totdeauna același caracter și se poate compara cu un șir de variații pe o singură temă. Din individualitatea sa structurala nu poate ieși nimeni, încât așa cum animalul în orice situație l-ai pune, rămâne strict mărginit în cercul strâmt în care natura i-a închis firea o dată pentru totdeauna, tot așa și omul prin individualitatea sa, prin caracterul, temperamentul și personalitatea lui, îi este deja stabilită cu mult înainte măsura comportamentului în viață. Indeosebi puterile intelectuale cu care este dotat i-au fixat capa- 
citatea pentru plăceri mai înalte. Dacă aceste puteri sunt reduse, atunci toate eforturile din afară, tot ce face omul, tot ce face soarta pentru el, nu vor fi în stare să-l ridice peste măsura stării lui de bine și a tihnei lui obișnuite, jumătate omenești, jumătate animalice; el rămânând înclinat spre plăcerea fizică, spre viata intimă și plăcută a familiei, spre relațiile sociale de rând și spre petrecerile vulgare.

Nici măcar cultura nu va putea să-l ajute prea mult deși întrucâtva aceasta îi întărește și lărgește orizontul sufletesc, căci plăcerile cele mai înalte, mai diverse și mai stabile sunt cele intelectuale, oricât ne-am înșela noi în tinerețe în privința lor. De aici se vede cât de mult are a face individualiatea noastră, respectiv personalitatea, în comparație cu ceea ce posedăm (avuția) ori reprezentăm în ochii altora, pentru că acestea depind de soartă, care se poate schimba oricând, fiind deci variabile. Cine își are avuția în interior, adica în mintea lui, acela nu va cere prea mult de la soartă, iar nerodul rămâne nerod până la sfârșitul vieții, „măcar de-ar fi în rai și înconjurat de hurii”; cum zice Goethe (West-Ostlicher „Divan):

„Popor, slugă şi stăpân, toți o spun în felul lor: cea mai mare fericire a omului pe pământ este numai propria sa personalitate."

Dacă acesteia i se adaugă o sănătate deplină, care depăşeşte toate bunurile materiale şi toate beneficiile poziției sociale, atunci întradevăr un cerşetor sănătos este mai fericit decât un împărat bolnav. Un temperament liniştit şi vesel izvorăşte dintr-o sănătate solidă şi dintr-o organizare anatomofiziologică armonioasă, o minte luminată, vie, pătrunzătoare şi dreaptă, o voinţă cumpătată şi blândă cu o conştiință limpede şi clară, toate acestea fiind însuşiri pe care nici funcțiile nici titlurile, nici avuția nu le pot înlocui. Este dovedit: ce este fiecare pentru sine însuşi, ceea ce îi rămâne în singuratate sau deplina linişte şi ceea ce nimeni nu-i poate da şi nici lua, este pentru el de mult mai mare importanță decât avuția sa, sau decât ceea ce poate fi el în ochii altora. Un om de spirit, un om dotat intelectual are o companie foarte bună cu propriile sale gânduri şi fantezii, pe când un cap cu intelect redus, alterat, nu poate scăpa de chinul plictisului, nici cu ceea mai variată schimbare de societăți, privelişti, excursii şi petreceri. Un caracter înăscut bun, măsurat şi blând poate fi mulțumit în situațiile cele mai neprielnice, pe când cel lacom, invidios şi răutăcios nu va fi mulțumit nici în mijlocul avuțiilor, iar dacă este vorba de un om care simte permanent în sine o individualitate extraordinară şi eminentă prin inteligența ei, pentru el mai toate plăcerile dorite de alții sunt de prisos, ba chiar o sarcină neplacută. De aceea zice Horatiu (Epistolarum II 2) despre sine: „Sunt mulți oameni care nu au nevoie de pietre scumpe, marmoră, fildeş, tablouri, statui, bani şi veşminte scumpe colorate cu purpură, dar este şi unul care nici nu vrea să le aibă”. La fel şi Socrate la vederea unor obiecte de lux expuse spre vânzare într-o piață zice: „Câte lucruri mai sunt de care nu am eu trebuință!’”.

Condiția cea mai importantă pentru starea de bine a omului este de fapt personalitatea lui, fie şi numai pentru că este stabilă şi lucrează în toate situațiile, nefiind supusă soartei precum avuția. În acest sens valoarea personalităţii se poate numi absolută şi prin natura ei nu stă deloc în puterea noastră să o dobândim după dorințele noastre, ci se întâmplă ,jure divino” şi este hotărâtă implacabil pentru toată viața, aplicându-se acel adevar nemilos: "Precum în ziua în care te-ai născut, soarele a salutat planetele în locuri hotărâte, aşa eşti întrupat şi tu şi creşti mai departe după legea înfințării tale. Aşa trebuie să fi şi nu poți scăpa de tine; aceasta este şi vechea învățătura a sibilelor şi a prorocilor. Şi nici un timp şi nici o putere pe lume nu poate sfărâma tiparul unei forme ce se dezvoltă în viață” (Goethe, Urworte, Orphisch).

Singurul lucru care stă în puterea noastră este doar modul prin care ne întrebuințăm personalitatea dată spre cel mai mare folos pe care îl permite şi să urmărim scopurile care-i corespund, căutând modelul dezvoltării conform caracteristicilor acesteia şi să ne alegem aceea condiție socială, ocupaţie şi mod de trai cu care ea se potriveşte şi se poate împăca. Un om înzestrat cu o putere musculară neobişnuită, dacă este silit să aibă o ocupație sedentară, sau să facă studii sau lucrări intelectuale care cer alt soi de facultăți rămase în afara firii lui, adică dacă nu îşi va putea întrebuința tocmai acele puteri cu care este înzestrat, se va simți nefericit toata viața; şi mai nefericit este acela care având facultăţi 
intelectuale este obligat să le lase neîntrebuințate pentu a se deda la munci de rând, sau pentru activități fizice intense, pentru care puterile sale nu sunt de ajuns.

Se impune păstrarea sănătăţii şi dezvoltarea facultăților cu care este omul înzestrat, mai degrabă decât insistența pentru dobândirea avuției; totuşi să nu se înțeleagă greşit ca nu este necesar să ne îngrijim pentru agonisirea celor necesare satisfacerii necesităților vitale. La drept vorbind bogăția cea mare valorează foarte puțin pentru personalitatea noastră, din care cauză mulți bogați se simt nefericiți fiindcă sunt fără cultura minții şi fără un obiectiv care să le preocupe intelectul. Ceea ce ne poate da bogăția pentru satisfacerea trebuințelor reale şi fireşti este de mică importanță pentru adevăratul nostru bine; chiar ne împiedică prin multele şi imperativele ei griji ce le aduce necesitatea păstrării unei averi prea mari. Şi totuşi oamenii caută de mii de ori mai mult să obțină bogăție decât cultura minţii; pe mulți îi vedem în mişcare neobosită, harnici ca furnicile, lucrând de dimineața până seara pentru a-şi spori bogăția, tot ce trece peste orizontul îngust al acestui scop rămâne necunoscut; mintea lor este închisă şi chiar resping alte gândiri şi simțiri. Plăcerile cele mai înalte, cele spirituale, le sunt străine, în zadar caută a le înlocui prin cele trecătoare, senzuale, precare, şi care le cer timp puțin şi bani mulți; la sfârşitul vieții au avere, pe care o vor lăsa moştenitorilor ca să o mărească, sau poate să o risipească.

În concluzie, ceea ce are fiecare om cel mai prețios în sinea lui este personalitatea sa, dar din pacate, această înzestrare de la natură este atât de rară, încât mai toți cei scăpați din luptele pentru existența zilnică datorită lipsurilor şi nevoilor, sunt tot atât de nefericiți ca şi cei care se află încă în aceste lupte. Aceasta se explică prin "golul” sufletesc, prin seceta conştiinței, a sărăciei minții, generând plictiseală şi împingerea spre grupurile compuse din acelaşi soi de oameni, întrucât "similes simili gaudet", urmând apoi alergatul după petreceri şi distracții în "high life"-ul societății, dorind să prefacă existența cea saracă într-un şir neîntrerupt de dorințe, pofte, bucurii şi plăceri, din care dezamăgirea nu poate lipsi, întrucât numeroasele neadevăruri ce ni le spunem unii altora în față sunt nedezlipite de o asemenea viață, unde se admit calităti de tot felul, în afară de cele intelectuale: acestea sunt de contrabandă... Aceste conveniențe sociale, ne silesc să avem o răbdare nemaipomenită pentru orice absurditate, nebunie sau prostie, pe câtă vreme însuşirile eminente ale cuiva aproape trebuie să-şi cerşească iertare sau să se ascundă, căci superioritatea intelectuală vatămă prin simpla ei existenţa şi fără voie. Cuvinte de duh sau inspirații inteligente se cuvin numai într-o societate inteligentă, în cea de rând naşte de-a dreptul invidia şi chiar ura; pentru a plăcea acolo, se cere să fii neaparat om de rând şi mărginit.

Personalitatea nu creşte în glastre sau în laboratoare, fiecare are "eul” lui prin care caută să-şi înalțe cota de prestigiu şi stimă; de la personalitate la celebritate drumul nu este scurt!. Fără cultivarea complexă a spiritului, fără cizelarea continuă a psihicului şi fără calități morale şi estetice, personalitatea individului ar fi incompletă şi chiar ar dăuna societății. 
Din perspectiva dvs., în calitate de medic, apreciați care dintre următoarele aspecte contribuie semnificativ la creșterea satisfacției profesionale și care nu contribuie:

PRESTIGIUL APARTENENTEI LA BREASL $\breve{A}$

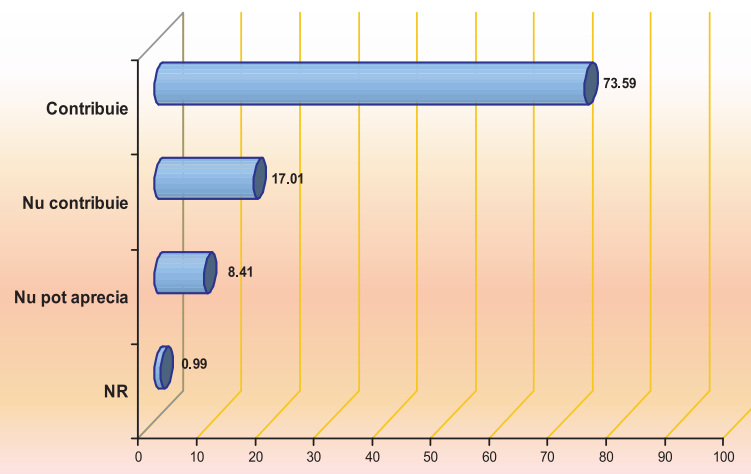

RECUNOAŞTEREA SIMBOLIC $\breve{A}$ ACORDATA DE CATRE PACIENȚI

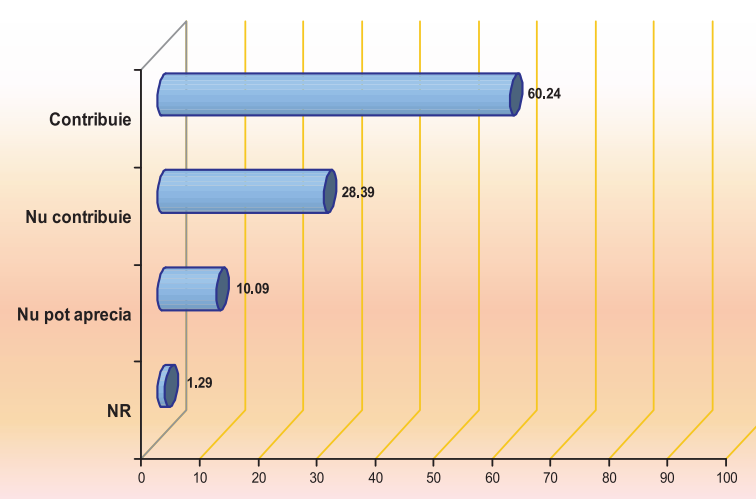

PRACTICAREA ÎN SINE A MESERIEI

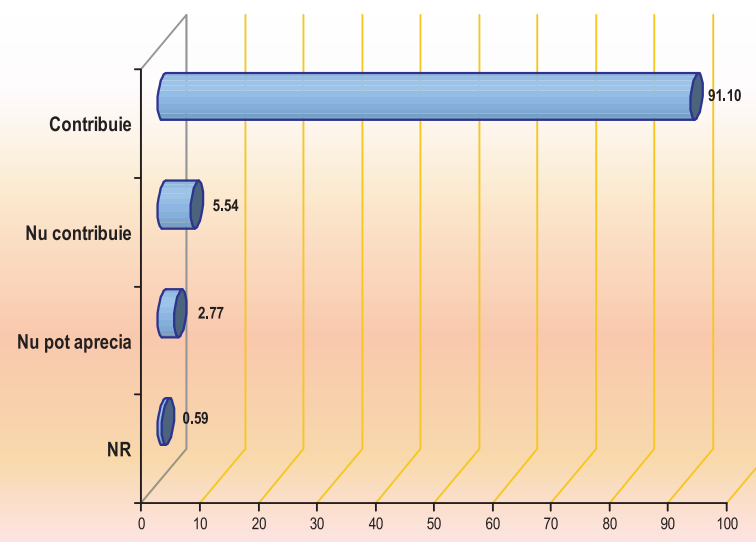

VIZIBILITATEA REZULTATELOR MUNCII

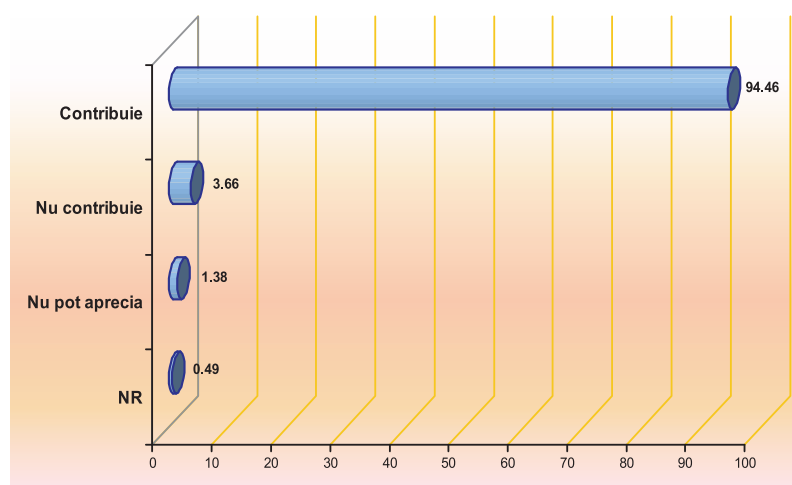

\section{APRECIEREA SUPERIORILOR}

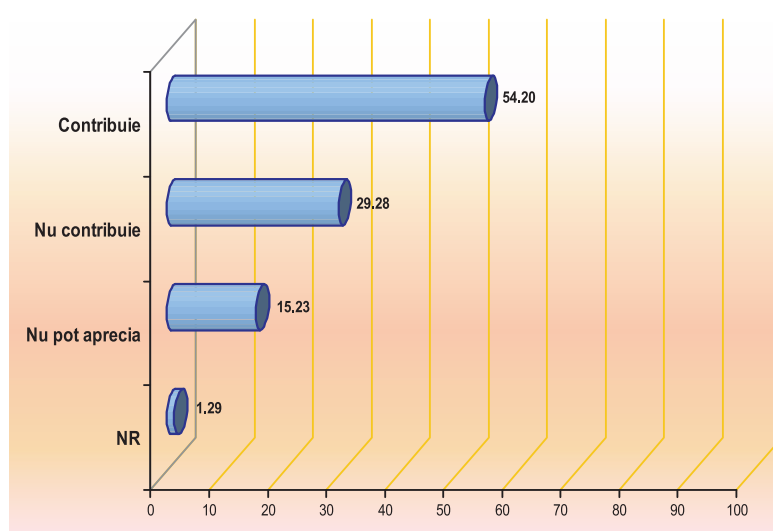

REMUNERAT,IA MUNCII, SPORURILE ŞI INDEMNIZATIILE AFERENTE

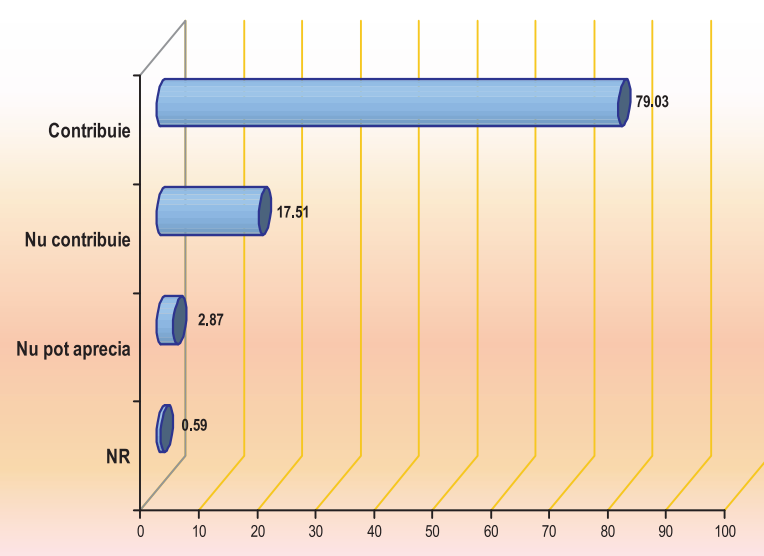


Evaluați care din următoarele aspecte ar motiva medicii din Romania într-o mai mare măsură şi ar fi în spiritul corectei lor aprecieri?

CREŞTEREA NIVELULUI GENERAL DE SALARIZARE

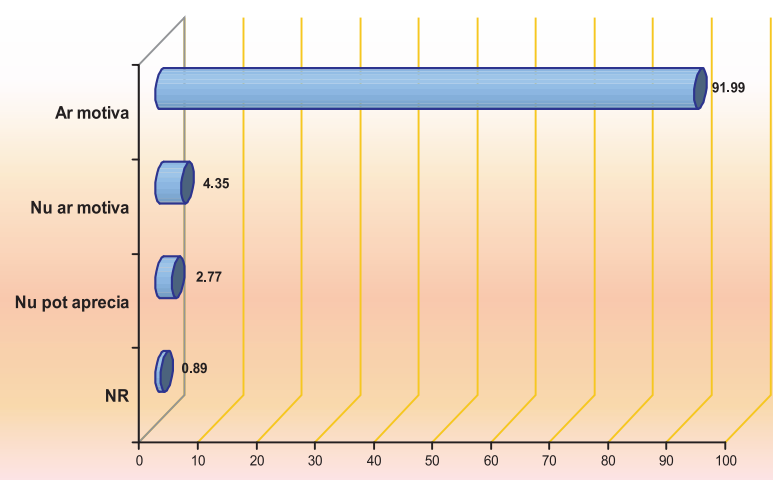

SALARIZAREA PERSONALULUI DIN DOMENIUL SANITAR ÎN FUNCT,IE DE PERFORMANT,

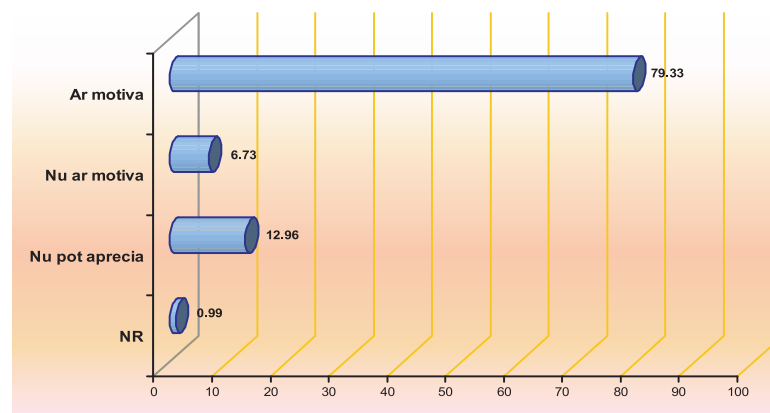

SALARIZAREA PERSONALULUI DIN DOMENIUL SANITAR ÎN FUNCT,IE DE RISCUL PROFESIONAL

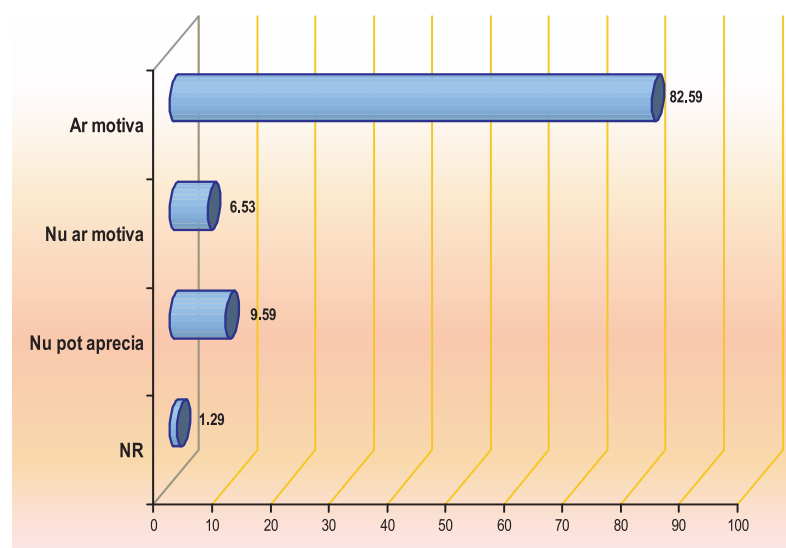

EVALUAREA LUNARA A PERSONALULUI ŞI ACORDAREA DE BONIFICAT⿱II

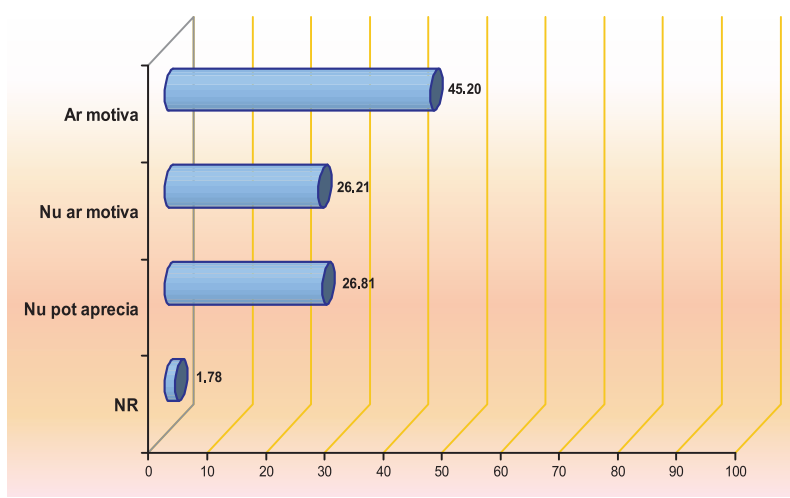

LEGALIZAREA PRIMIRII DE “ATENȚII / CADOURI"

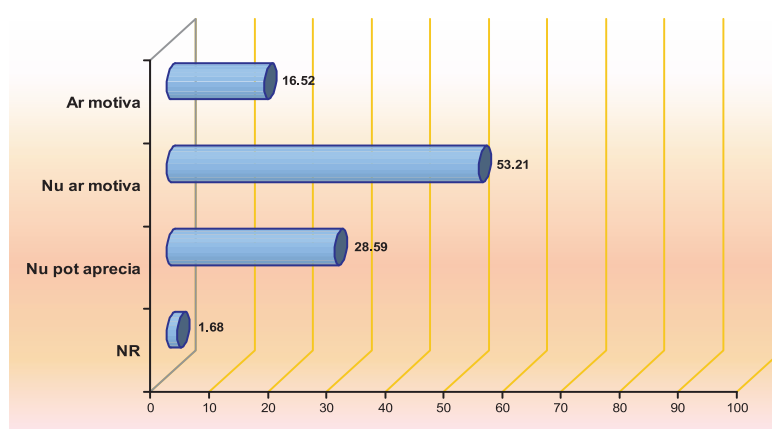

Cât de mulțumit sunteți de nivelul actual al salarizării medicilor din România?

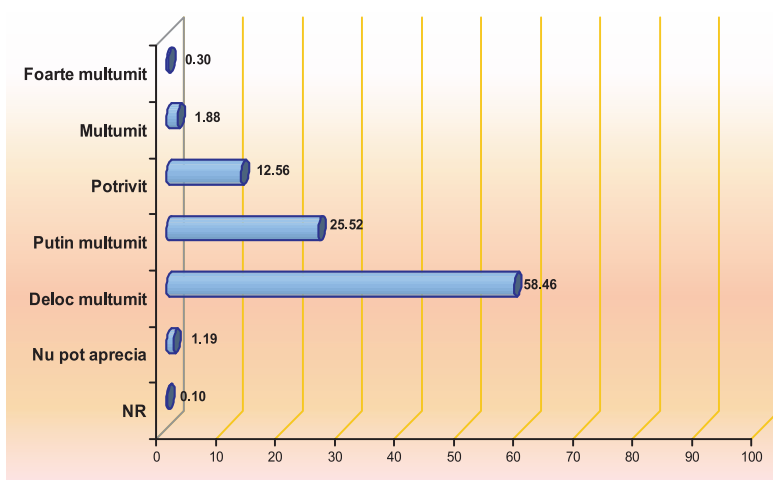


Cât de mulțumit sunteți de următoarele aspecte care privesc condițiile generale în care își desfăşoară activitatea personalul din domeniul sanitar:

STAREA FIZICA SI IGIENICÄ A

CLĂDIRILOR DIN SERVICIILE PUBLICE DE SANATATE (DE STAT) - SPITALE, CLINICI, SANATORII, ETC

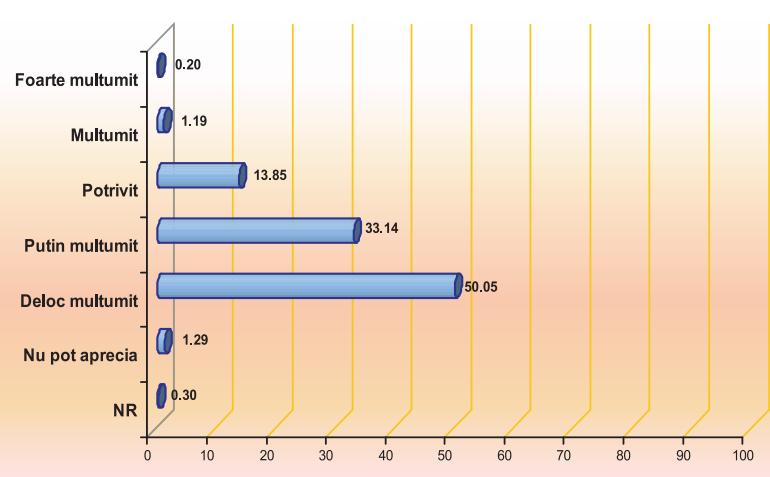

DOTAREA CU MIJLOACE DE

INTERVENTIIE ÎN CAZ DE URGENT⿱Ä AMBULANȚE, PERSONAL CALIFICAT, INSTRUMENTAR MEDICAL ADECVAT

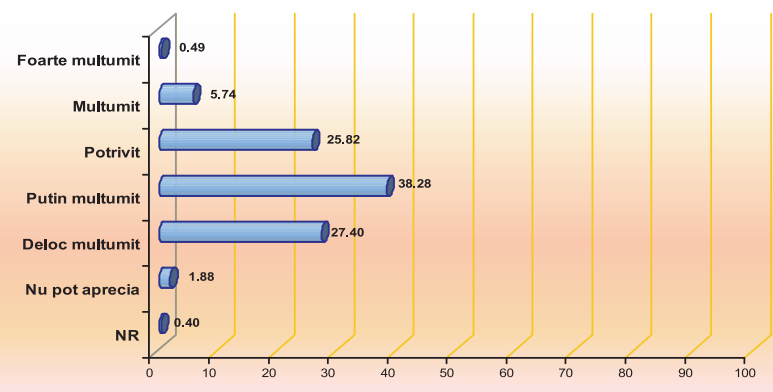

CAPACITATEA DE LUCRU A UNITĂŢLOR SANITARE (NUMĂR DE PATURI)

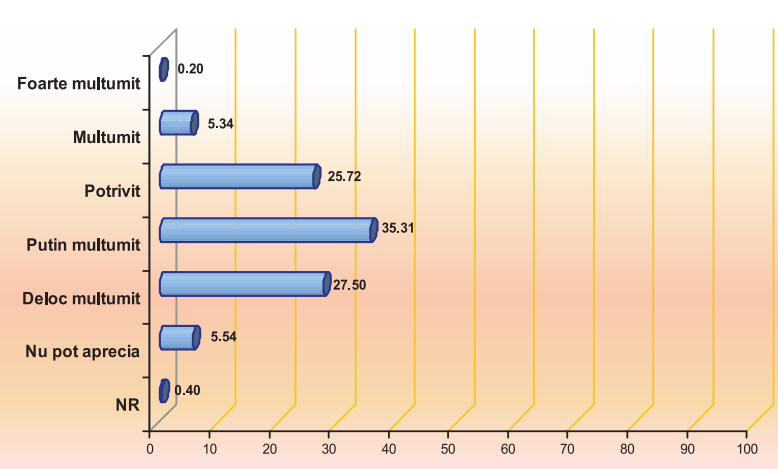

NUMĂRUL DE PERSONAL ANGAJAT FAT, A DE NECESAR

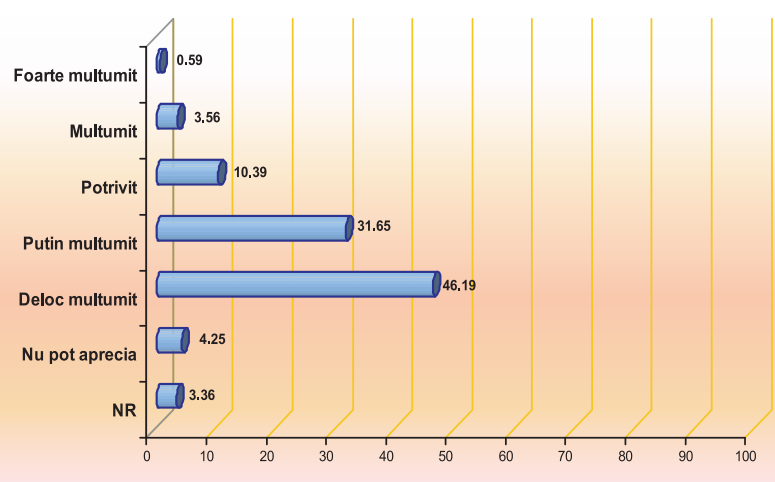

DOTAREA TEHNICA A UNIT $\breve{A T I L O R}$ SANITARE (ECHIPAMENTE)

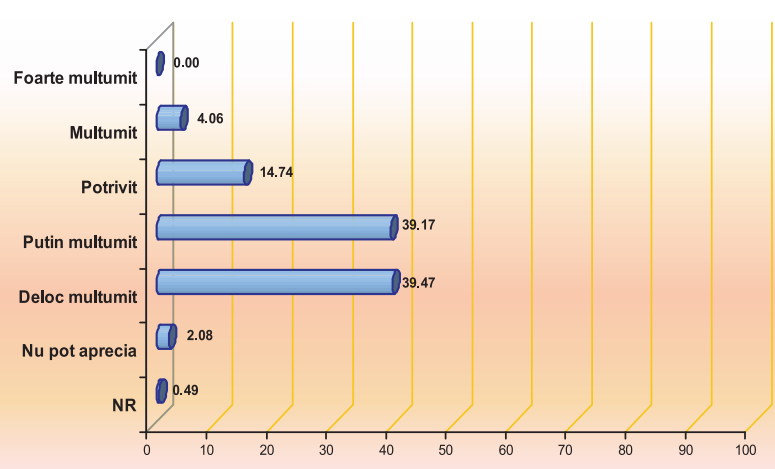

\section{ASIGURAREA NECESARULUI DE MEDICAMENTE}

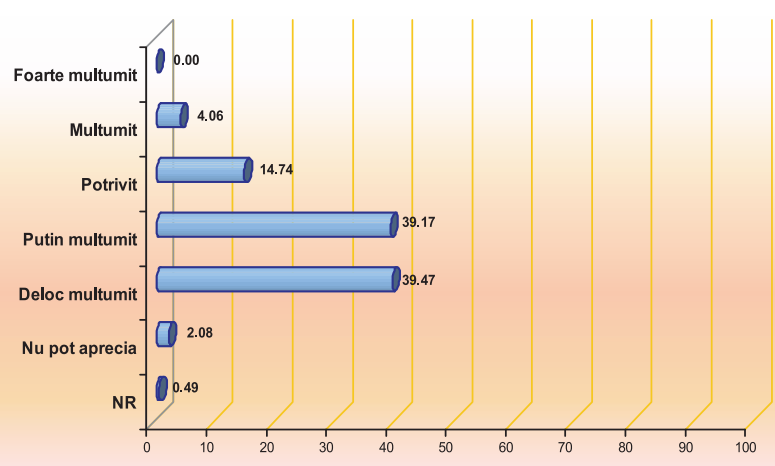


În ce măsură credeți că sunt apreciate meritele profesionale ale medicilor de către restul societăţii?

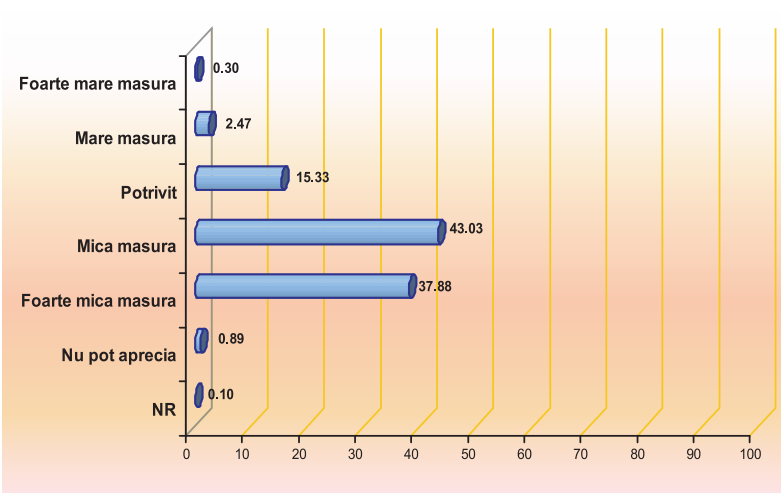

Dacă vă raportați la volumul şi natura muncii, cum considerați că sunt veniturile dvs.?

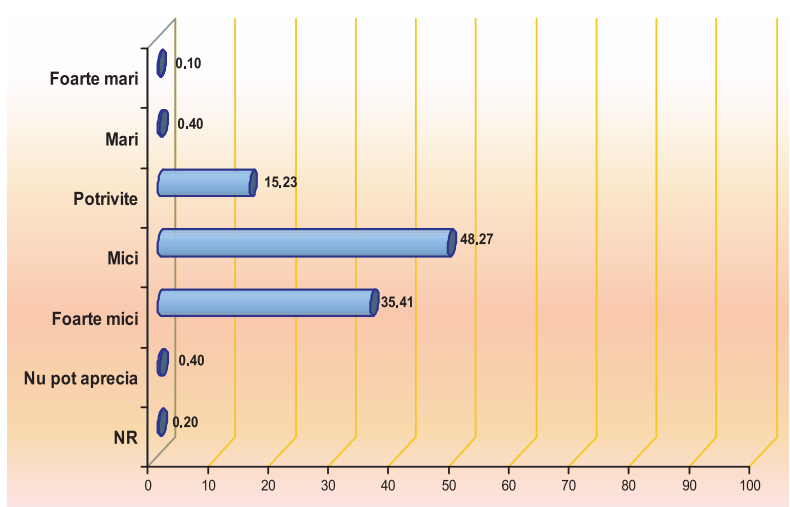

Apreciați cu note de la 1 la 10 ( 1 = foarte proaste, $10=$ foarte bune $)$ calitatea următoarelor tipuri de relații de muncă:

RELATIILE CU MANAGERII DIN ADMINISTRAȚIE

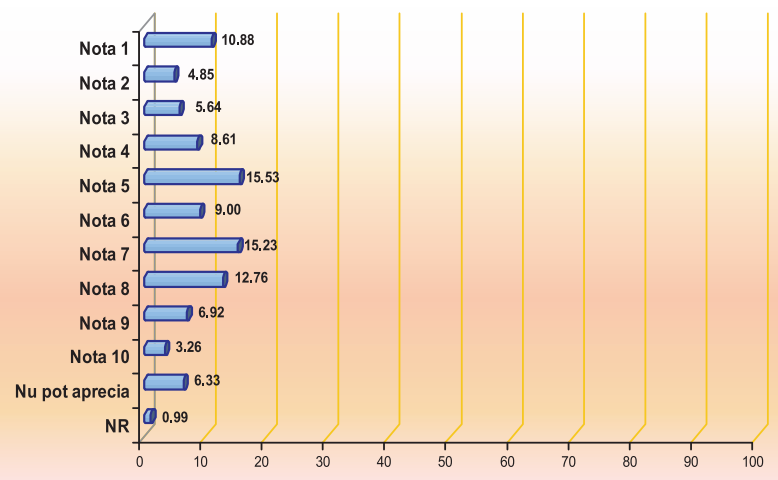

RELATTIILE CU SUPERIORII PE LINIE PROFESIONAL $\breve{A}$

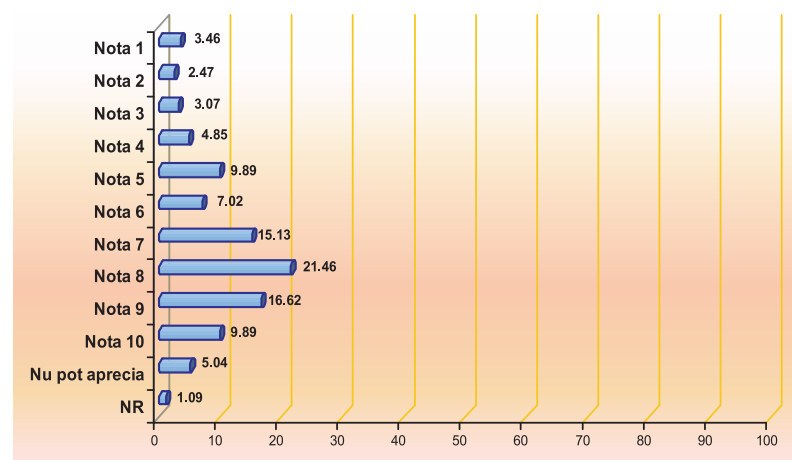

RELATIILE CU PERSONALUL DIN SUBORDINE

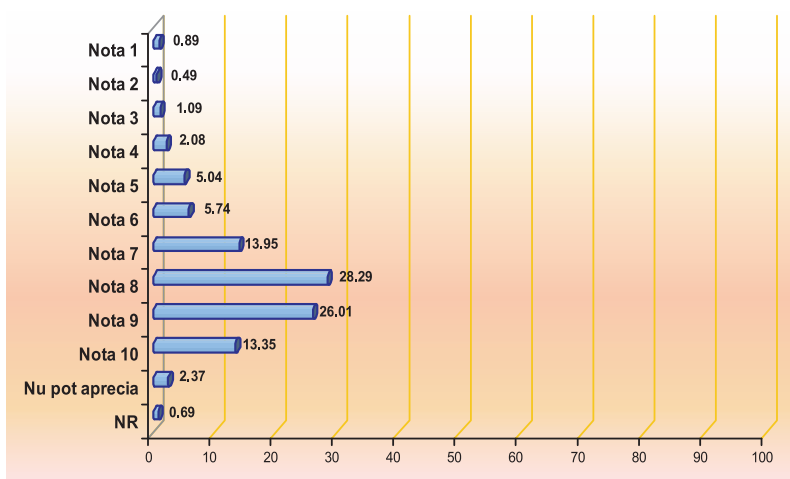

RELATTILE CU PERSONALUL DIN ALTE UNITÁTI DE PROFIL

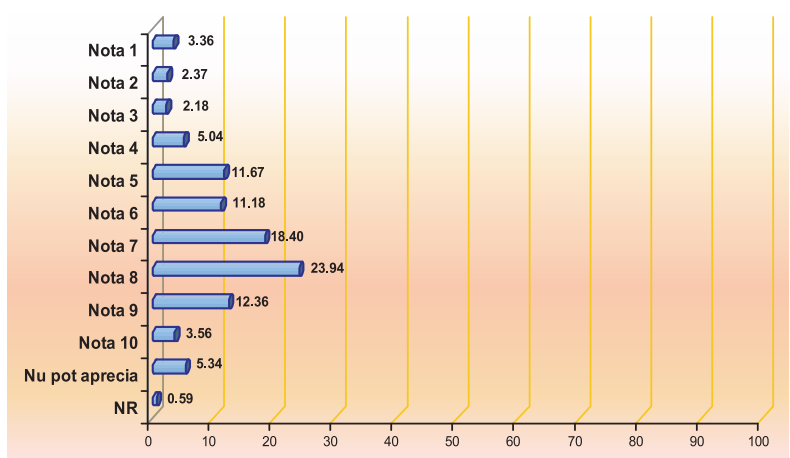


Cum apreciați că este nivelul birocrației din sistemul sanitar?

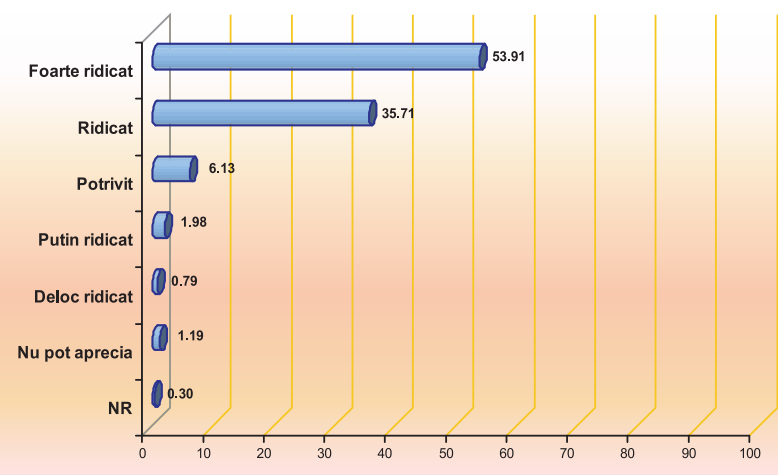

Cât de des se întâmplă ca, din motive ce țin de funcționarea sistemului, să nu puteți acorda îngrijire medicală pacienților, la timp şi la standarde maxime?

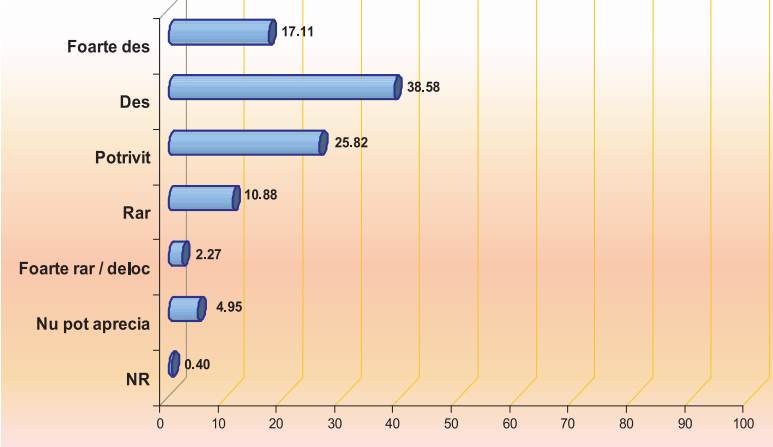

Gândindu-ne la timpul liber care vă este necesar față de cel pe care îl aveți la dispoziție, cât de mulțumit sunteți de actuala stare a lucrurilor?

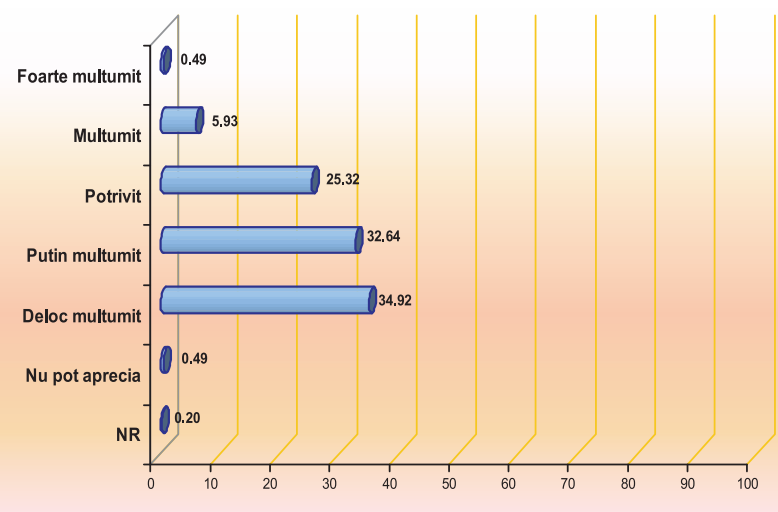

Cât de des se întâmplă să folosiţi timpul liber în scopuri profesionale?

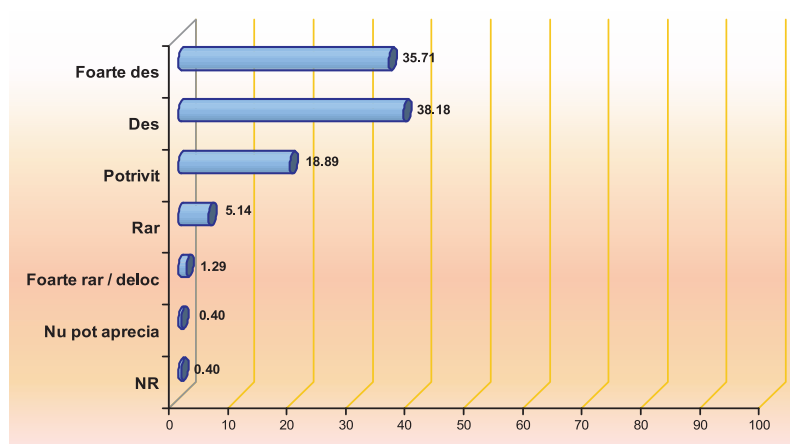

În ce sens considerați că vă influențează viața personală (şi de familie) domeniul în care vă desfăşurați activitatea?

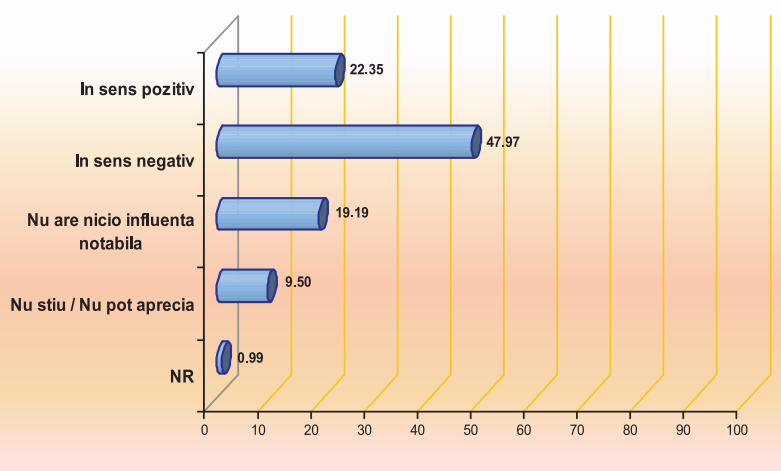

În ultimii ani, foarte multe cadre medicale din România au plecat în străinătate pentru a munci. Dvs. personal ați dori să emigrați?

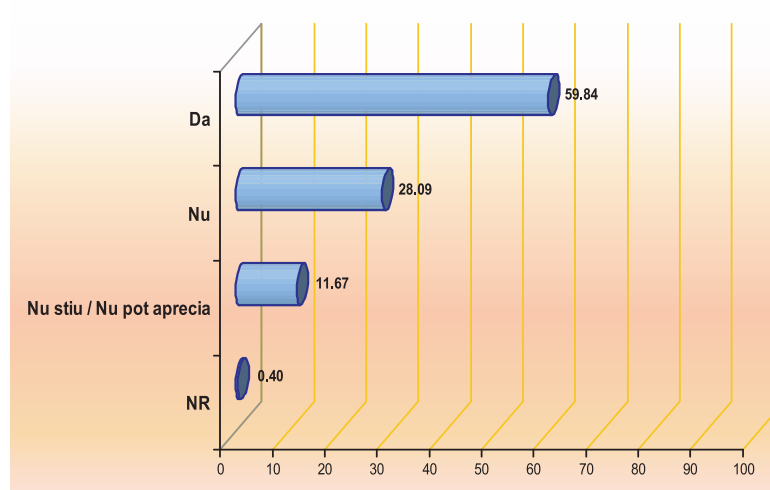


Care credeți că sunt principalele 3 probleme care afectează calitatea serviciilor medicale din România?

\section{PRIMA ALEGERE}

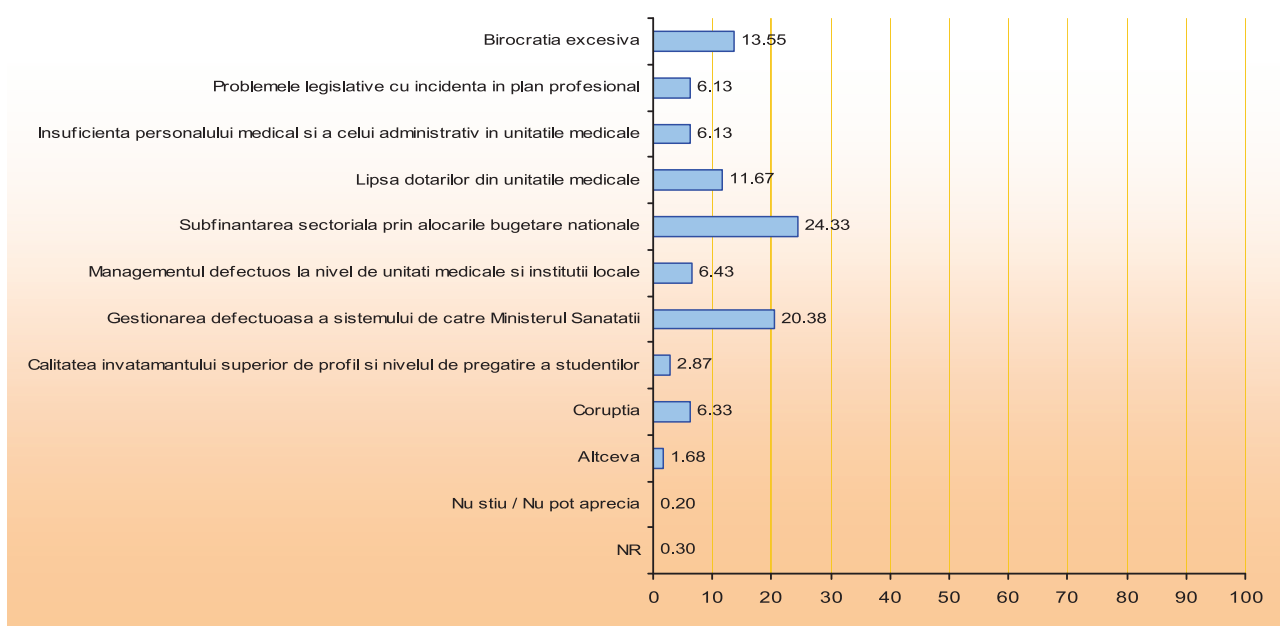

\section{A DOUA ALEGERE}

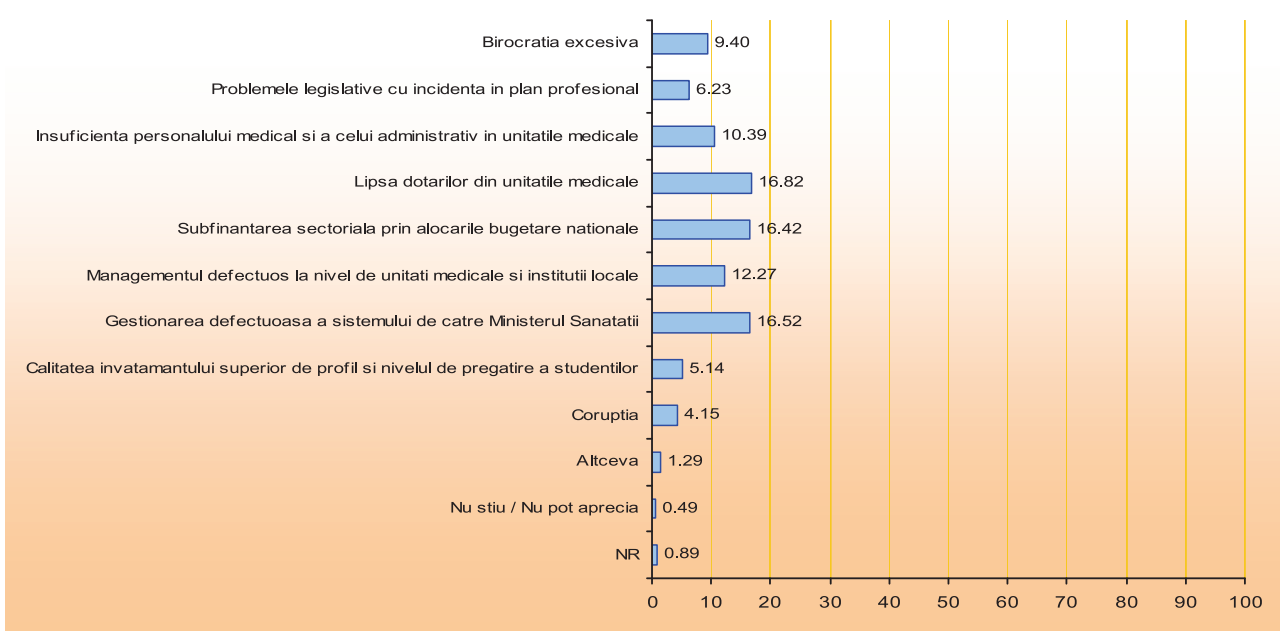

\section{A TREIA ALEGERE}

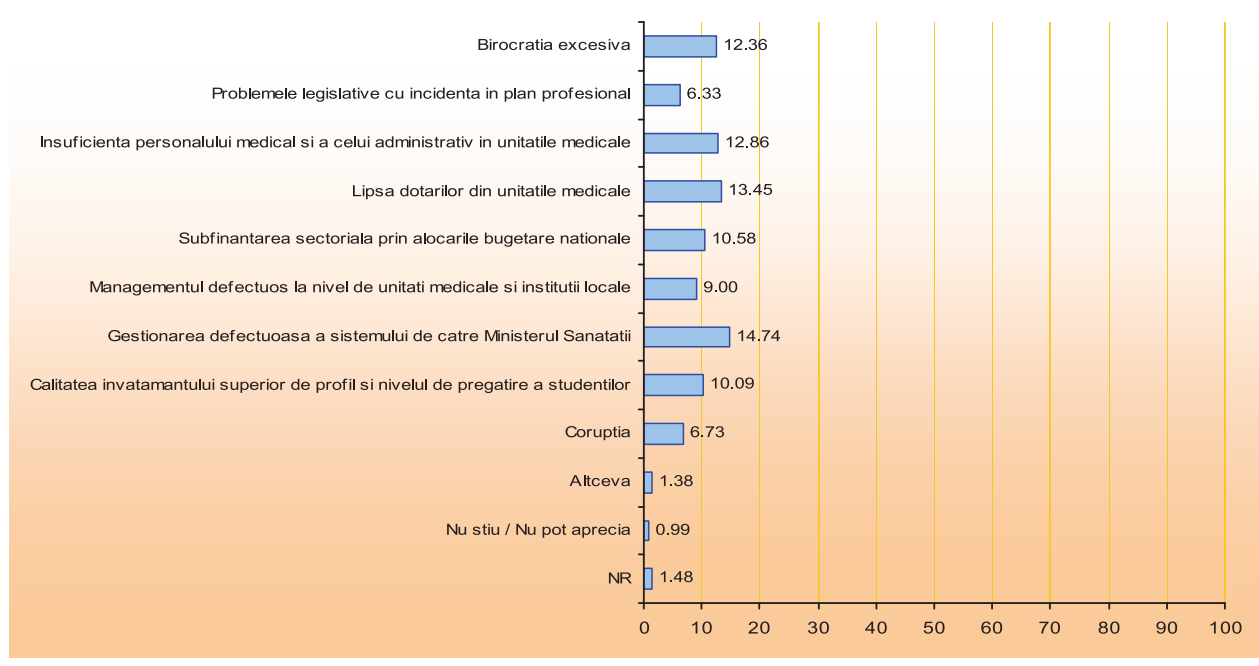


Cât de mult vă doriți să emigrați?

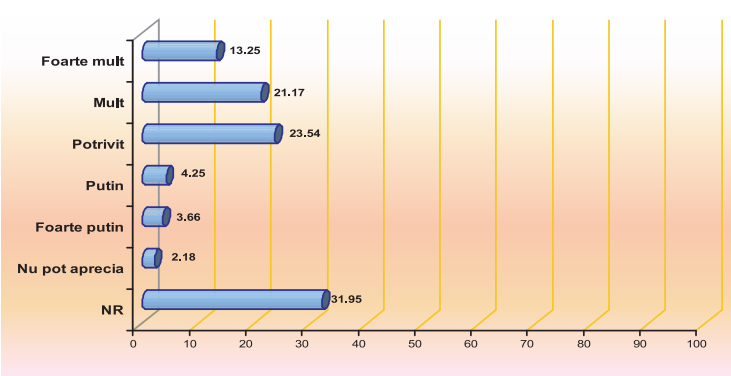

Care sunt principalele 3 aspecte care vă motivează intenția emigrării?

PRIMA ALEGERE

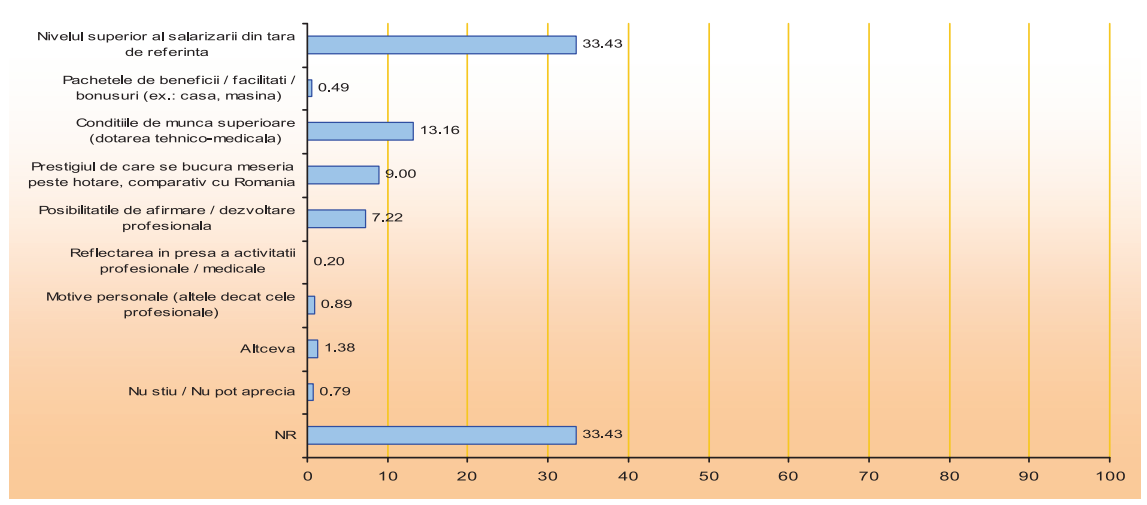

A DOUA ALEGERE

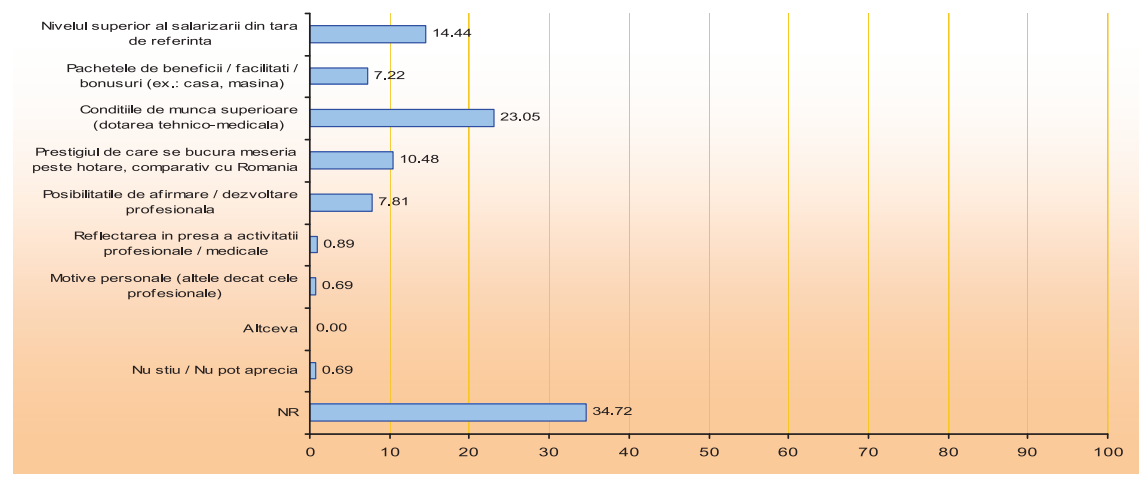

A TREIA ALEGERE

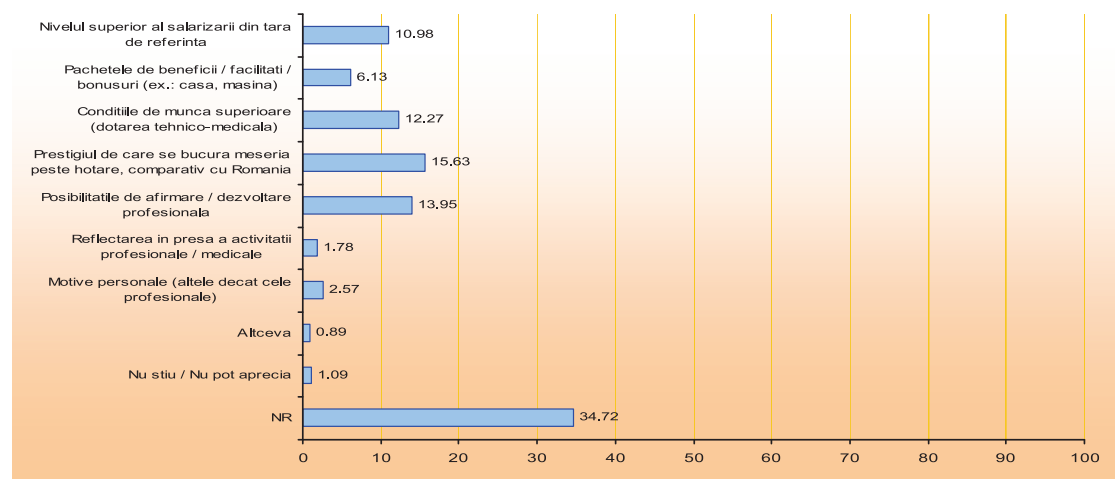


Cum considerați că este procentul din PIB acordat sănătății de către actualul Guvern $(4 \%)$, raportat la necesități?

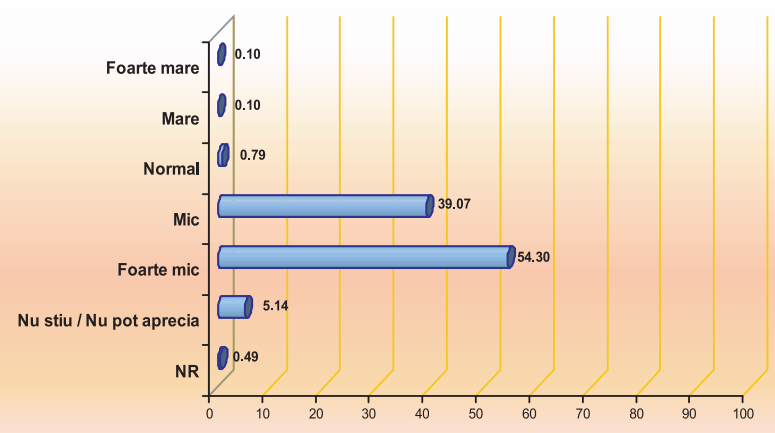

Există un proiect cu privire la înființarea unui parteneriat formal (instituționalizat) între furnizorii de servicii medicale - medici şi beneficiarii acestora - pacienți. În ce măsură credeți că 0 astfel de asociere ar fi benefică pentru optimizarea funcțională a sistemului sanitar şi ar produce avantaje ambilor parteneri?

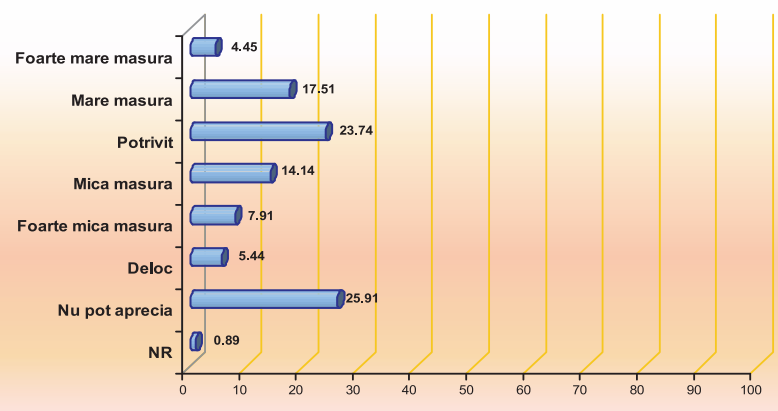

Printr-o evaluare de ansamblu, acordați o notă de la 1 la 10 funcționării actuale a sistemului sanitar în Romania (1 = foarte proastă, 10 = foarte bună)

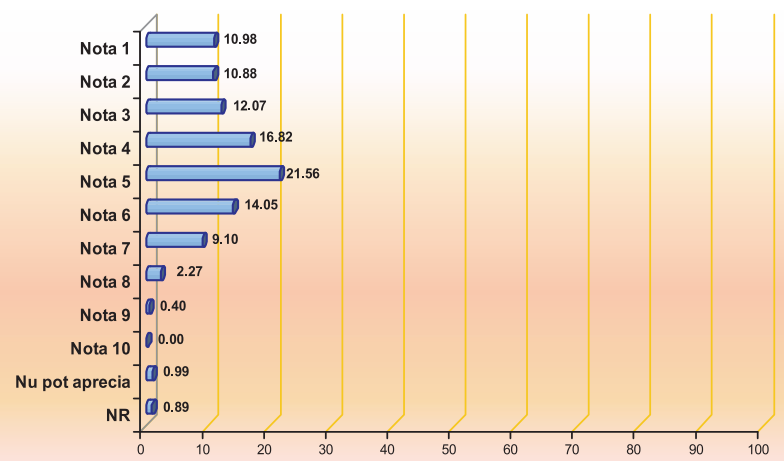

Care este, cu aproximație, venitul dvs. personal lunar, cumulat din practica profesională?

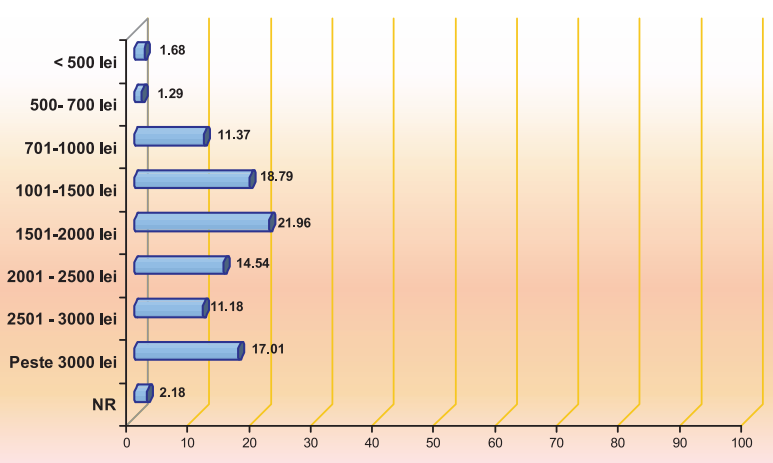

Care este vechimea dvs. în calitate de medic angajat (în sectorul de stat sau / şi privat)?

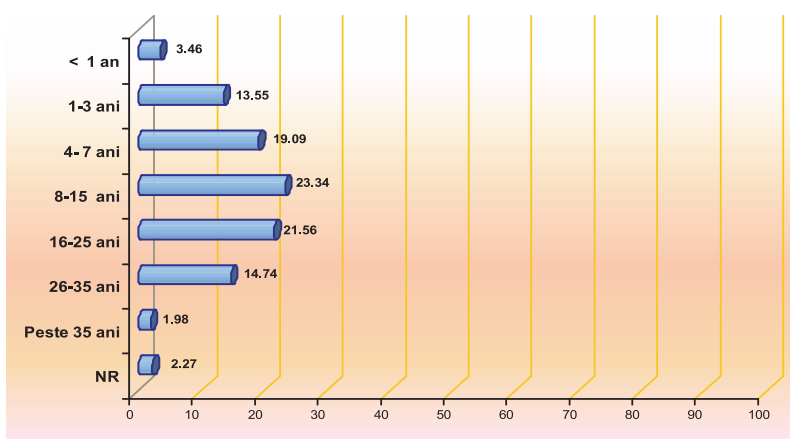

Precizați care este gradul profesional pe care îl aveți momentan

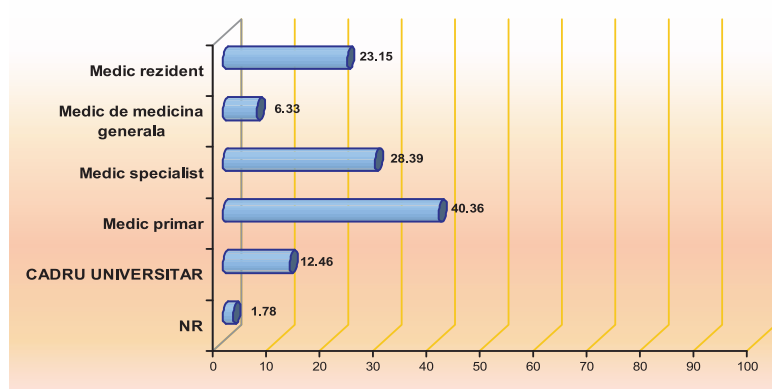

În care dintre următoarele tipuri se încadrează activitatea pe care o desfăşurați în mod curent?

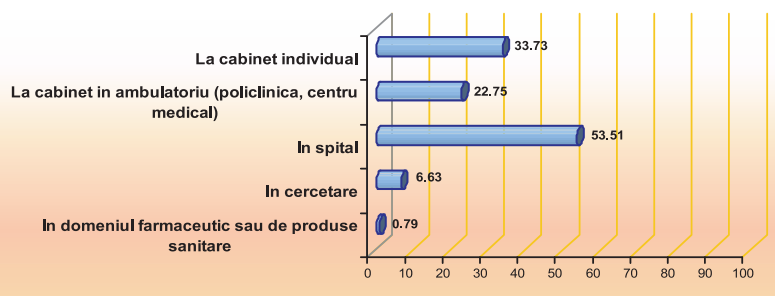


În opinia dvs., cei din lista de mai jos sunt afectați pozitiv (au de câștigat) sau negativ (au de pierdut) ca urmare a abordărilor negative din mass-media?

MEDICII ÎN GENERAL (DIN ÎNTREAGA TARA)

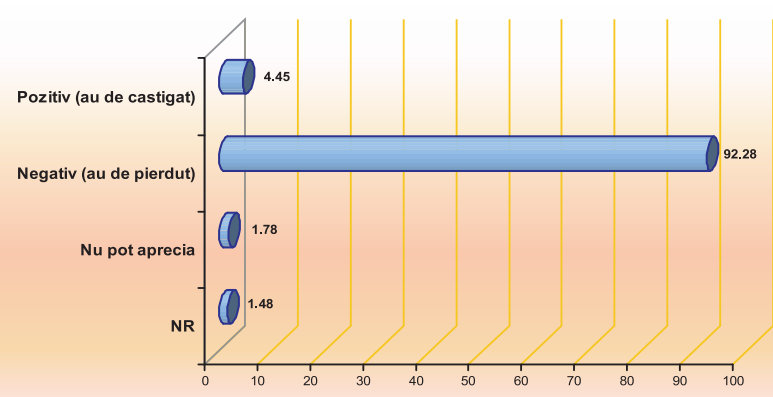

MEDICII DIN UNITATTILE SANITARE AFLATE INN SUBIECTELE DE PRESĂ

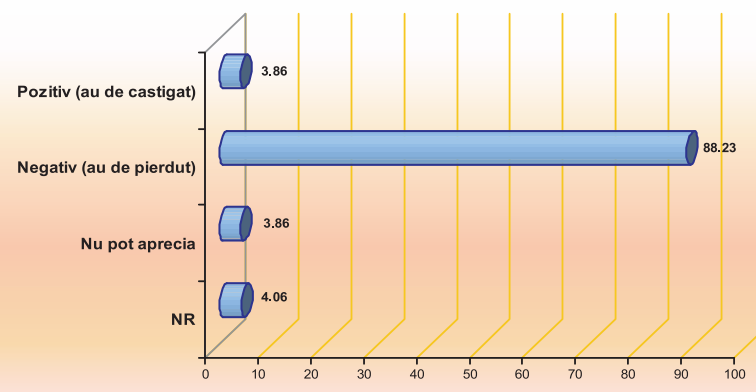

PACIENT⿱II ÎN GENERAL (DIN ÎNTREAGA TQAR $\breve{A)}$

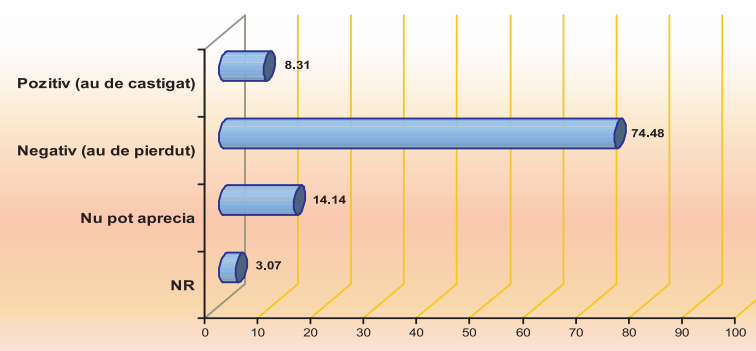

PACIENT⿱II DIN COMUNITATTILE LOCALE AFLATE ÎN SUBIECTELE DE PRES $\breve{A}$

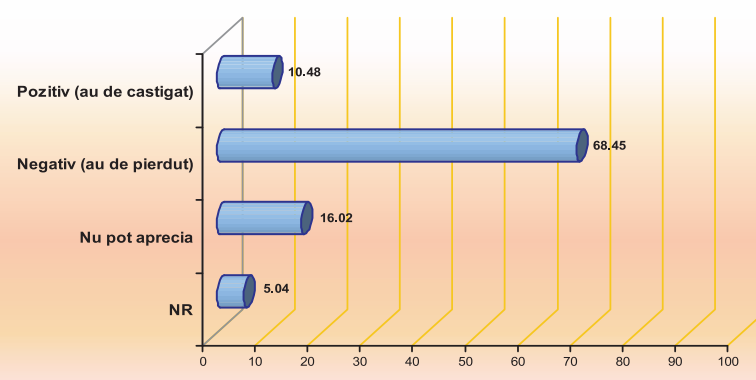

INVĂTĂMÂNTUL UNIVERSITAR DE PROFIL

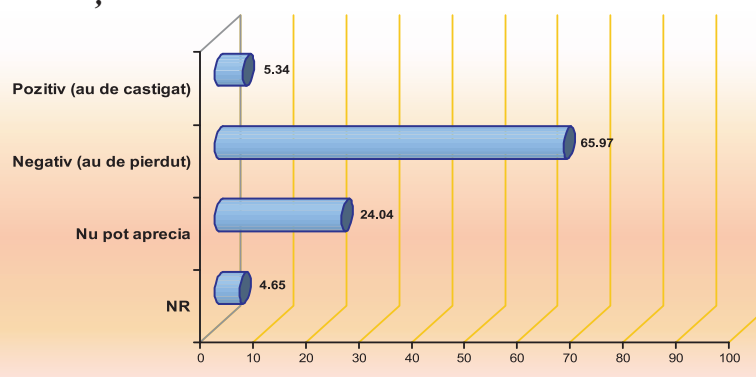

MINISTERULS S $\breve{A T T A T I I I}$

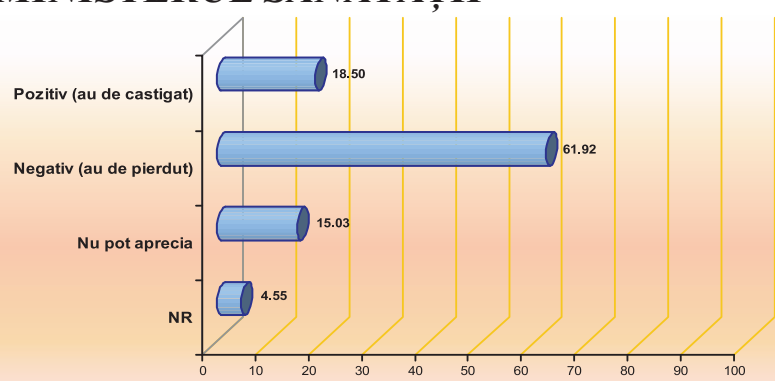

GUVERNUL ROMÂNIEI

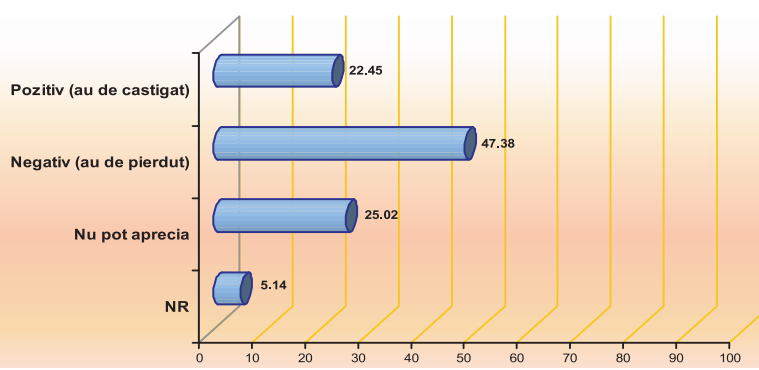

ROMÂAIA, CA NATIUUE

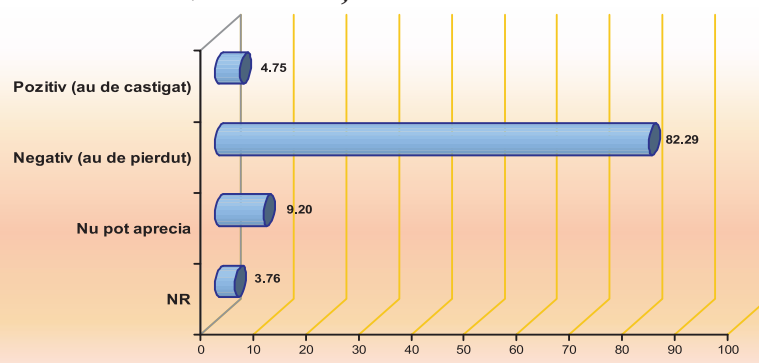

TRUSTURILE DE PRESA

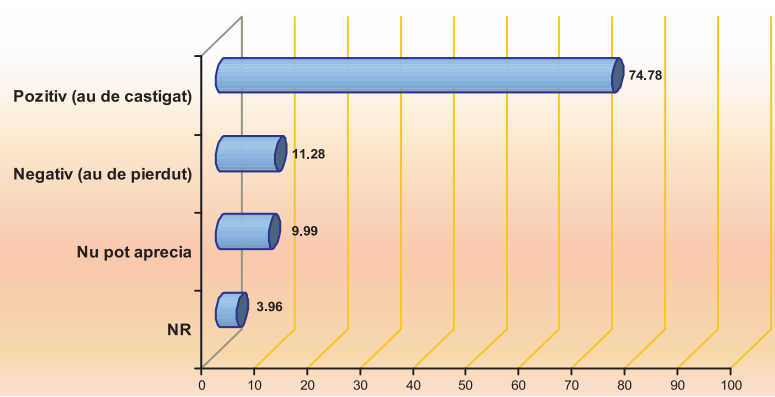

